\title{
The reality of remembrance in Camperdown Memorial Rest Park
}

\section{Hannah Robinson}

University of Technology Sydney, Faculty of Arts and Social Sciences, PO Box 123, Ultimo NSW 2007, Australia. hannah.k.robinson@student.uts.edu.au

Disclaimer: Aboriginal and Torres Strait Islander People are advised that some deceased persons are mentioned within this text.

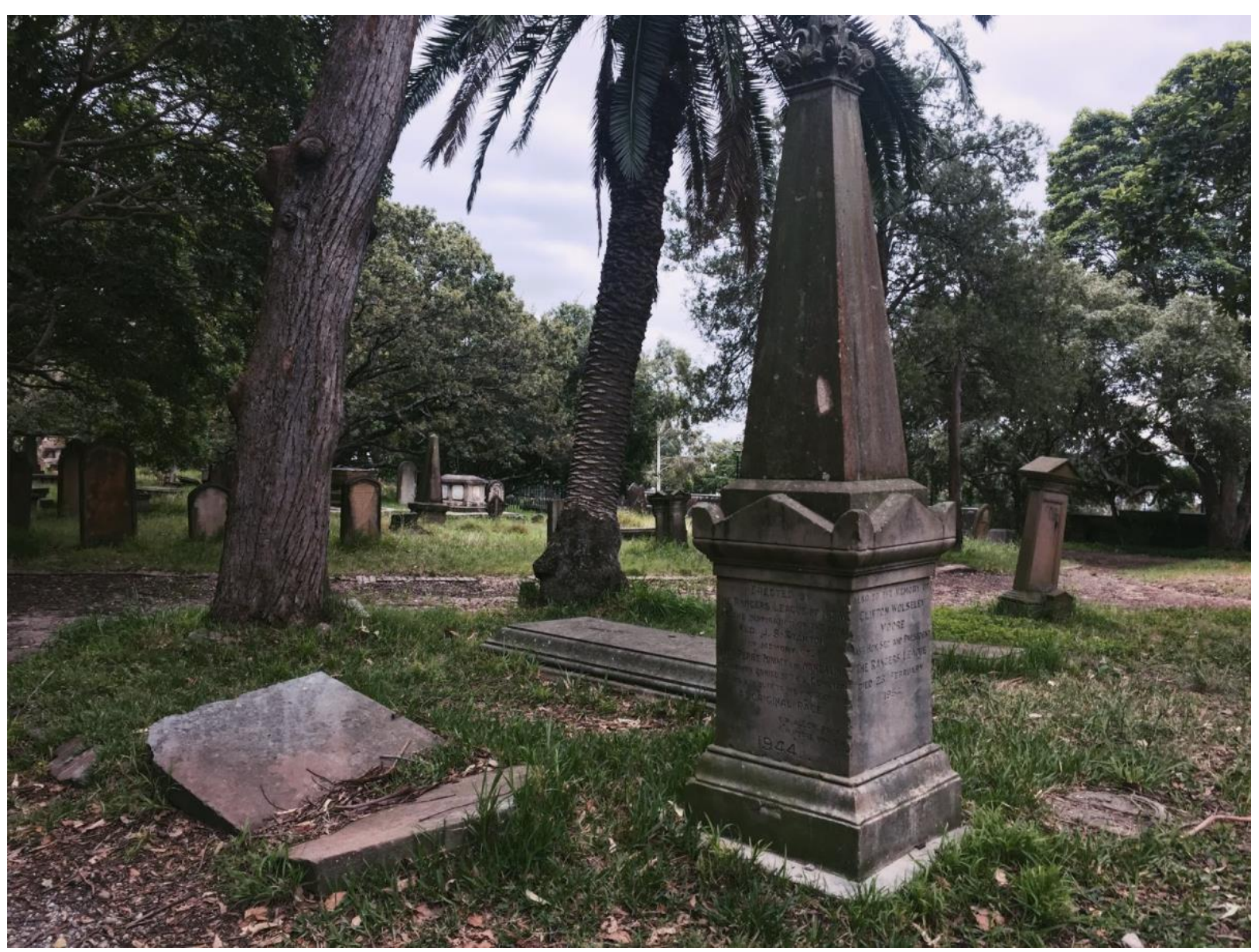

Nestled at the back of Newtown, behind the bustling King St and amongst the Camperdown suburbia, lies Camperdown Memorial Rest Park, a frequent spot for gatherings with friends, and a beloved dog hang-out for owners and canines alike. However, not many people know (c) (i) Copyright 2019 by the author. This is an Open Access article distributed under the terms of the Creative Commons Attribution 4.0 Unported (CC BY 4.0) License (https://creativecommons.org/licenses/by/4.0/), allowing third parties to copy and redistribute the material in any medium or format and to remix, transform, and build upon the material for any purpose, even commercially, provided the original work is properly cited and states its license.

NEW: Emerging scholars in Australian Indigenous Studies is a Student Journal from UTS ePRESS showcasing outstanding student works. 
of the deep cultural significance that this park holds for Aboriginal people. The strong historical importance that lies beneath the surface of the park and within the park's closed off section are found within Camperdown Cemetery.

On entry to the cemetery, I was taken aback by the huge Moreton Bay Fig Tree, a native flora towering over the entrance. Immediately, the huge St Stephen's Church came into view looking to oversee the grounds scattered with headstones obvious, from a glance, that this cemetery is hundreds of years old (being first erected in 1849).

I was in search for the 'Rangers' League of NSW Memorial' gravestone that is there to commemorate Mogo, William Perry, Tommy, and Wandalina; all of whom are buried within this cemetery. Each were Aboriginal People; Mogo died on the 5th of October 1850, and William Perry died 25th September 1849. My search found to be difficult as featured on the same monument was the gravestone of another man, Clifton Wolseley, who was not known to be an Aboriginal man. His side of the stone was facing frontwards, which meant when I first walked through the cemetery, I missed the memorial because it faced the wrong way. When I eventually found the memorial, under the listing of the deceased Aboriginal people it stated, 'Also as a tribute to the whole of the Aboriginal Race'.

This baffled me. The state of the monument which had been previously vandalised, and the grouping of Aboriginal people as a collective rather than individually being given burial sites, seemed to contradict this message.

On further investigation into this site's history, I discovered due to the original cemetery being closed down in 1942 - resulting in what is now known as Camperdown Memorial Rest Park - the location of the original burial sites for the deceased Aborigines is unknown, and the exact number of Aboriginal people buried within the park cannot be confirmed. The placement of this memorial is jarring in contrast to the tall towers of St Stephen's Church, the hundreds of middle-class colonial people buried on the site and to the unkempt nature of the cemetery.

I was left to wonder, on a site so significant to Aboriginal heritage, why is it that the majority of people are unaware of its importance? A tree was planted with a plaque in 1932 in the 'Cooee Corner' of the park which still stands to this day, highlighting another commemorative piece given to deceased Aboriginal people. This memorial was erected in memory of Mogo and planted in the place believed to have other Aboriginal People buried. Yet still, little is done to inform the community of the importance of these sites. I left feeling both moved and challenged; questioning our recognition of important memorials of burial sites and acknowledging the stark reality of commemoration of British colonials versus that of Aboriginal people. As I passed back through the Moreton Bay Fig and through the scarcely scattered flora, I understood the loss of integrity given to this sacred site which lies on Gadigal Country. 


\section{References}

Hinkson, Melinda, Harris, Alana, 'Aboriginal Sydney' Second Edition 2010, 'Site 24 Memorial to Aboriginal Burials, Camperdown Cemetery pp. 84 - 85

Newtown Project, 'Camperdown Cemetery', City of Sydney 2000-2014, viewed 02/04/2019 https://www.newtownproject.com.au/.../cadigal-newtown-intr.../4/ 